\title{
EFFECT OF AMINOETHOXYVINILGLYCINE (AVG) ON PREHARVEST FRUIT DROP AND MATURITY OF APPLES ${ }^{1}$
}

\author{
CASSANDRO VIDAL TALAMINI DO AMARANTE², ANDERSON SIMIONI ${ }^{3}$, CLARICE APARECIDA MEGGUER ${ }^{3}$, \\ LUIZ EDUARDO BASSAY BLUM ${ }^{4}$
}

\begin{abstract}
Apple trees cultivars Gala and Fuji were sprayed four weeks before commercial harvest with aminoethoxyvinilglycine (AVG), at doses of 0,125 , or $250 \mathrm{mg} \mathrm{L}^{-1}$, and assessed for preharvest fruit drop, fruit growth, and maturation on tree. In 'Gala', 64 days after AVG spraying, fruit drop for control treatment was $85 \%$, and AVG (at 125 and $250 \mathrm{mg} \mathrm{L}^{-1}$ ) reduced it to $10 \%$. In 'Fuji', 64 days after AVG spraying, fruit drop for control was $6 \%$, while treatments with AVG (at 125 and $250 \mathrm{mg} \mathrm{L}^{-1}$ ) increased fruit drop to $10 \%$. AVG was a powerful retardant of fruit maturation for 'Gala' but not for 'Fuji'. In 'Gala', the most affected attribute was the skin background color, followed, in decreasing order, by soluble solids content, the starch index, skin red color, the flesh firmness, and titratable acidity. In 'Gala', only flesh firmness retention was improved by increasing AVG dose from $125 \mathrm{mg}$ $\mathrm{L}^{-1}$ to $250 \mathrm{mg} \mathrm{L}^{-1}$. The AVG at $250 \mathrm{mg} \mathrm{L}^{-1}$ inhibited "Gala" late fruit growth but not 'Fuji'.
\end{abstract}

Index terms: Malus domestica Borkh., regulator, ethylene, fruit growth, fruit quality.

\section{EFEITO DO TRATAMENTO COM AMINOETOXIVINILGLICINA (AVG) NA QUEDA PRÉ-COLHEITA E NA MATURAÇÃO DOS FRUTOS EM MACIEIRAS}

RESUMO - Macieiras, das cultivares Gala e Fuji, foram pulverizadas quatro semanas antes do início da colheita comercial dos frutos com aminoetoxivinilglicina (AVG), nas concentrações de $0 ; 125$ ou $250 \mathrm{mg} \mathrm{L}^{-1}$, e avaliadas quanto à queda de frutos na pré-colheita, o crescimento e maturação dos frutos. Na cultivar Gala, 64 dias após a pulverização com AVG, a queda pré-colheita no tratamento-controle era de $85 \%$, mas os tratamentos com AVG (125 e $\left.250 \mathrm{mg} \mathrm{L}^{-1}\right)$ reduziram esta queda para 10\%. Na cultivar Fuji, 64 dias após a pulverização com AVG, a queda de frutos no tratamento-controle era de $6 \%$, e os tratamentos com AVG (125 e $\left.250 \mathrm{mg} \mathrm{L}^{-1}\right)$ aumentaram esta queda para $10 \%$. Tratamentos com AVG retardaram substancialmente a maturação dos frutos da cultivar Gala, mas não da 'Fuji'. Na cultivar Gala, o atributo mais afetado foi a cor de fundo da casca, seguido, em ordem decrescente, pelo conteúdo de sólidos solúveis totais, índice de iodo-amido, cor vermelha da casca, firmeza de polpa e acidez titulável. Na cultivar Gala, apenas a retenção de firmeza de polpa foi significativamente aumentada com o aumento na concentração de AVG de 125 mg $\mathrm{L}^{-1}$ para $250 \mathrm{mg} \mathrm{L}^{-1}$. A concentração de $250 \mathrm{mg} \mathrm{L}^{-1}$ inibiu o crescimento final de frutos na cultivar Gala, mas não na 'Fuji'.

Termos para indexação: Malus domestica Borkh., Biorregulador vegetal, etileno, crescimento de frutos, qualidade de frutos.

\section{INTRODUCTION}

Aminoethoxyvinilglycine (AVG) is a potent inhibitor of ethylene biosynthesis that inhibits the conversion of S-adenosyl methionine to 1-aminocyclopropane-1-carboxylic acid (Yang \& Hoffman, 1984). Pre and postharvest applications of AVG have been evaluated for enhancement of production and quality attributes of climacteric fruits.

Preharvest abscission and ripening of apples are events regulated by ethylene (Masia et al., 1998; Ward et al., 1999). Apple fruit abscission shortly before harvest is the most frequent recurring problem, thereby reducing potential yield. Ethylene stimulates increasing synthesis and activity of cellulase and polygalacturonase in the abscission zone of apple causing preharvest fruit drop (Ward et al., 1999). Apple growers often utilize the synthetic auxin, naphthaleneacetic acid (NAA), which can suppress preharvest fruit abscision, but the product does not delay fruit maturation on the tree (Masia et al., 1998). On the other hand, AVG can reduce fruit ethylene production, reducing preharvest fruit drop and the incidence of premature fruit ripening on the tree (Bramlage et al., 1980). The product may increase yield by reducing preharvest fruit drop and increasing fruit size of late harvested fruit. Delaying harvest may provide flexibility for scheduling of labor, fruit processing and packaging, cold storage, and marketing.

Pre and postharvest treatments with AVG suppressed ethylene production and delayed ripening of pear (Romani et al., 1983; Clayton et al., 2000), peach (Ju et al., 1999), kiwifruit (Manriquez et al., 1999), avocado (Starrett \& Laties, 1991), and muskmelon (Shellie, 1999). In 'Golden Delicious' apples, AVG sprayed four weeks before harvest inhibited ethylene production, reduced preharvest drop, delayed fruit maturation on the tree and fruit ripening and softening during storage (Bramlage et al., 1980; Autio \& Bramlage, 1982; Masia et al., 1998). Bramlage et al.
(1980) found that the magnitude of delayed ripening in apples was dependent on cultivar and AVG concentration. Preharvest treatments with AVG reduced cuticular free phenolics, alpha-farnesene accumulation and oxidation, and scald development on apples (Ju \& Bramlage, 2000). AVG sprays reduced the incidence of water core and maturity cracking in apples particularly when the harvest was delayed beyond the optimum harvest date (Autio \& Bramlage, 1982). However, AVG might impair fruit quality by inhibiting volatiles production (Fan et al., 1998; Mir et al., 1999; Harb et al., 2000) and development of red color of the skin (Layne et al., 2000; Wang \& Dilley, 2001). Nevertheless, the application of ethephon after treatment with AVG reversed the negative effect of AVG on fruit flavor and red color development of the skin in apples (Mir et al., 1999; Wang \& Dilley, 2001).

This work was conducted to study the effects of different doses of AVG, sprayed four weeks before commercial harvest, on preharvest drop, fruit growth and maturity of 'Gala' and 'Fuji' apples.

\section{MATERIALSAND METHODS}

The experiment was conducted in a commercial orchard in Lages, Santa Catarina State, Southern Brazil. Twelve-years-old apple trees, cultivars Gala and Fuji, grafted on Marubakaido rootstock, were sprayed four weeks before commercial harvest with aminoethoxyvinilglycine (AVG; ReTain $^{\mathrm{TM}}, 15 \%$ a.i. p/p, Abbott Laboratories Inc. - Agricultural Products, IL, USA), at doses of 0,125 , or $250 \mathrm{mg}$ (a.i.) $\mathrm{L}^{-1}$, and assessed for preharvest fruit drop, fruit growth and evolution of fruit maturity on the tree. 'Gala' apples were sprayed on 16 January 2001 and 'Fuji' apples were sprayed on 2 March 2001.

The experiments to investigate the effects of different doses of AVG on preharvest fruit drop of 'Gala' and 'Fuji' followed a completely

1 (Trabalho 049/2002). Recebido: 12/03/2002. Aceito para publicação: 26/09/2002.

Ph.D., Centro de Ciências Agroveterinárias (CAV), Universidade do Estado de Santa Catarina (UDESC), Cx. Postal 281, CEP 88502-970, Lages, SC, Brasil. E-mail: amarante@cav.udesc.br.

2 Estudante do Curso de Agronomia, Centro de Ciências Agroveterinárias (CAV), Universidade do Estado de Santa Catarina (UDESC), Cx. Postal 281, CEP 88502970, Lages, SC, Brasil. Bolsista de Iniciação Científica do CNPq.

3 Ph.D., Centro de Ciências Agroveterinárias (CAV), Universidade do Estado de Santa Catarina (UDESC), Cx. Postal 281, CEP 88502-970, Lages, SC, Brasil. E-mail: a2lbb@cav.udesc.br. 
randomized block design with five replicates. Whole trees were blocks and single-scaffold limbs per tree were the experimental units. Three branches in the medium part of each tree were labeled, and each branch was separated from the surrounding branches by plastic sheets and sprayed with the AVG solutions containing an organo-silicon surfactant $(0.1 \% \mathrm{v} / \mathrm{v}$ Silwet L-77) up to dripping. The treatments were applied in a random distribution on separate branches of each tree. All the fruit from each limb were counted and marked with a waterproof ink pen. The percentage of dropped fruit was evaluated weekly until 64 days and 84 days after AVG spraying on 'Gala' and 'Fuji', respectively.

To investigate the effects of different doses of AVG on fruit growth and maturation on 'Gala' and 'Fuji' tree, three branches in the medium part of each of 40 trees in the same row were labeled, and each branch was sprayed with the AVG treatments described above. All fruits from each labeled branch of four replicate trees were harvested and assessed for average fruit weight and maturity, starting at the date of AVG spraying until 64 and 91 days after the treatment for 'Gala' and 'Fuji', respectively. Samples of 20 fruit of uniform size per replicate were assessed for maturity at each harvest date. Skin background color was assessed by means of a color chart (ENZA New Zealand International) on a scale of 1 (dark-green) to 8 (yellow-green). Flesh firmness $(N)$ was determined on two sides of each fruit using a hand held penetrometer (Effegi FT 327, fitted with an $11.1 \mathrm{~mm}$ diameter head). Soluble solids content (SSC; ${ }^{\circ}$ Brix) was determined with a hand refractometer (Abbe Atago) on a composite juice sample collected during the pressure test. The starch pattern index (using the starch iodine test) was scored on a scale of 1 to 5 , where 1 indicates the least and 5 the most starch to sugar conversion. Titratable acidity (meq. malic acid/100 mL) from juice composite samples of five fruits was determined by titrating to $\mathrm{pH} 8.2$ with $0.1 \mathrm{~N} \mathrm{NaOH}$.

Statistical analysis of the data was performed using the SAS system (SAS, 1990). Analysis of variance (ANOVA) was performed using the PROC GLM procedure; the best fit was achieved using the PROC REG or PROC NLIN procedures. Percentage data was transformed to arc $\sin [(x+5) / 100]^{1 / 2}$ before being submitted to the ANOVA.

\section{RESULTS AND DISCUSSION}

Preharvest fruit drop on 'Gala' was much higher than on 'Fuji' (Figure 1). AVG was highly effective in suppressing fruit drop of 'Gala' while on 'Fuji' the product slightly increased fruit drop. On 'Gala', 64 days after AVG spraying, fruit drop for the control treatment was $85 \%$, and $\mathrm{AVG}$ at $125 \mathrm{mg} \mathrm{L}^{-1}$ and $250 \mathrm{mg} \mathrm{L}^{-1}$ reduced this number to $10 \%$ (Figure 1A). In 'Fuji', 64 days after AVG spraying, fruit drop for the control was $6 \%$, while treatments with AVG at $125 \mathrm{mg} \mathrm{L}^{-1}$ and $250 \mathrm{mg} \mathrm{L}^{-1}$ increased fruit drop to $10 \%$ (Figure 1B).

On 'Gala', the increase of fruit weight was similar between treatments until 30 days after spraying the trees (Figure 1C). At the end of this period, fruit weight averaged between treatments was $151 \mathrm{~g}$. Thirtyfive days latter, fruit treated with AVG at $125 \mathrm{mg} \mathrm{L}^{-1}$ had an increment of fruit weight of $12.5 \%$, increasing to $170 \mathrm{~g}$. However, 'Gala' treated with AVG at $250 \mathrm{mg} \mathrm{L}^{-1}$ did not show further increments in weight 30 days after treatment (Figure 1C). On 'Fuji', fruit weight was not affected by AVG (Figure 1D). For this cultivar fruit growth showed a bell shape curve, with an increase in fresh matter accumulation until 45-50 days after spraying, followed by a decrease thereafter. This decrease of fruit weight might indicate a mobilization of reserves from the fruit to the wood as a result of changes of physiological status of the trees towards dormancy in autumn (Faust, 1989).

AVG at $250 \mathrm{mg} \mathrm{L}^{-1}$ seems to be toxic for 'Gala', inhibiting late fruit growth, but not for 'Fuji' (Figure 1). This might indicate different sensibility of these cultivars to AVG. High doses of AVG also reduced fruit size at harvest of apples (Williams, 1980) and peaches (Dekazos, 1981) and caused leaf chlorosis in muskmelon (Shellie, 1999). Considering that AVG inhibits enzymes that use the cofactor pyridoxal phosphate, such as ACC synthase (Yang \& Hoffman, 1984), it might be fore- seen that a high dose of the product is able to inhibit other metabolism processes in the plant required for fruit growth in some apple cultivars.
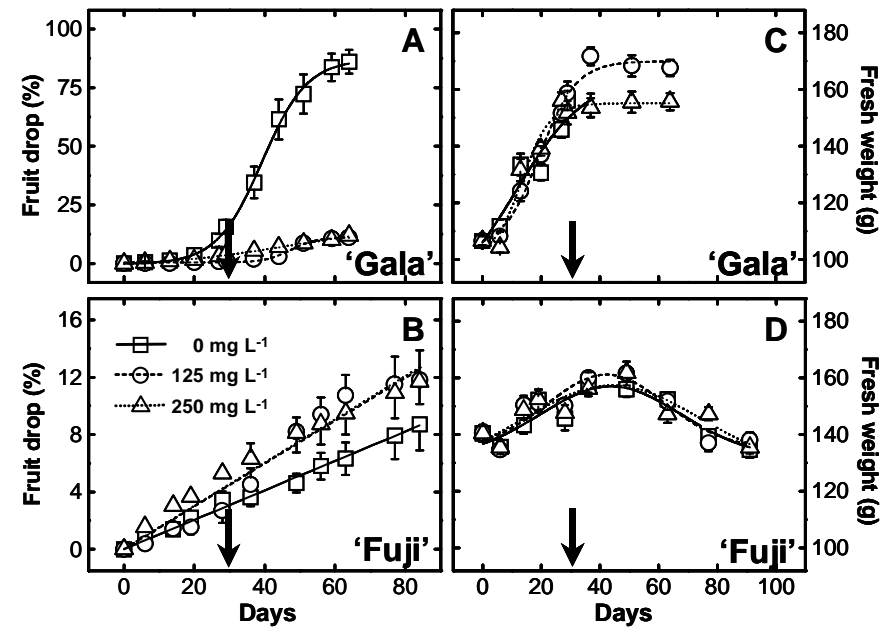

FIGURE 1 - Effect of AVG on preharvest fruit drop (A, B) and fruit growth $(\mathrm{C}, \mathrm{D})$ of 'Gala' and 'Fuji' apples. Arrows indicate the initial commercial harvest for the control treatment of each cultivar. The bars represent the standard error of the means $(n=5)$. The $x$ axis represents days after AVG spraying. Note the difference on fruit drop scale for 'Gala' and 'Fuji' (A, B).

AVG had a more substantial effect in delaying fruit maturation on trees of 'Gala' than 'Fuji' (Figure 2). On 'Gala', only flesh firmness retention was substantially improved by increasing AVG dose from 125 $\mathrm{mg} \mathrm{L}^{-1}$ to $250 \mathrm{mg} \mathrm{L}^{-1}$ (Figure $2 \mathrm{~F}$ ); for the other attributes, no additional benefit was achieved by using the highest AVG dose (Figure 2).

On 'Gala', the most expressive effect of AVG was the retention of skin background color, followed, in decreasing order, by the delay on changes of soluble solids content, starch pattern index, red color development of the skin, flesh firmness, and titratable acidity (Figure 2). The linear models adjusted for the evolution of skin background color, soluble solids content, starch pattern index, skin red color, and titratable acidity indicated that fruit treated with AVG $\left(125-250 \mathrm{mg} \mathrm{L}^{-1}\right)$ required additionally $53,40,34,28$, and 8 days, respectively, to achieve the same level of maturity of the control treatment at the commercial harvest (Figure 2). The loss of flesh firmness was delayed in about 12 and 20 days with AVG at doses of $125 \mathrm{mg} \mathrm{L}^{-1}$ and $250 \mathrm{mg} \mathrm{L}^{-1}$, respectively, in comparison to the control (Figure 2F).

On 'Fuji', changes in skin background color, soluble solids content, starch pattern index, skin red color, titratable acidity, and firmness were delayed by AVG (125-250 $\left.\mathrm{mg} \mathrm{L}^{-1}\right)$ in 10, 9, 10, 11, 4, and 2 days, respectively, in comparison to the control fruits harvested at the commercial maturity (Figure 2).

The results show that 'Gala', which produces high quantities of ethylene (Saquet \& Streif, 2000) and, therefore, is highly susceptible to preharvest fruit drop and rapid maturation on the tree, substantial commercial benefits may be achieved with the use of AVG. On 'Gala', AVG at $125 \mathrm{mg} \mathrm{L}^{-1}$ may increase yield by reducing premature fruit abscission and by increasing fruit size of late harvested fruit. On the other hand, 'Fuji' produces small amounts of ethylene (Saquet \& Streif, 2000) and AVG lack the capacity to reduce fruit drop and to delay fruit maturation on the tree. In fact, AVG seems to be toxic on 'Fuji', causing an increase of fruit drop in comparison to untreated controls (Figure 1B).

On 'Gala', considering flesh firmness to characterize fruit maturity, the treatment with AVG at $125 \mathrm{mg} \mathrm{L}^{-1}$ delayed fruit harvest in 12 days. This delay in fruit harvesting would result in an increase of fruit weight average of $9 \%$. This treatment also suppressed preharvest fruit drop. The preharvest drop of the control at commercial harvest was $16 \%$, while fruit treated with $\mathrm{AVG}$ at $125 \mathrm{mg} \mathrm{L}^{-1}$ and harvested 12 days latter had a preharvest drop of $3 \%$. Therefore, AVG at $125 \mathrm{mg} \mathrm{L}^{-1}$, by delaying 
fruit harvest in about 12 days allowed an increase of fruit yield of more than $20 \%$
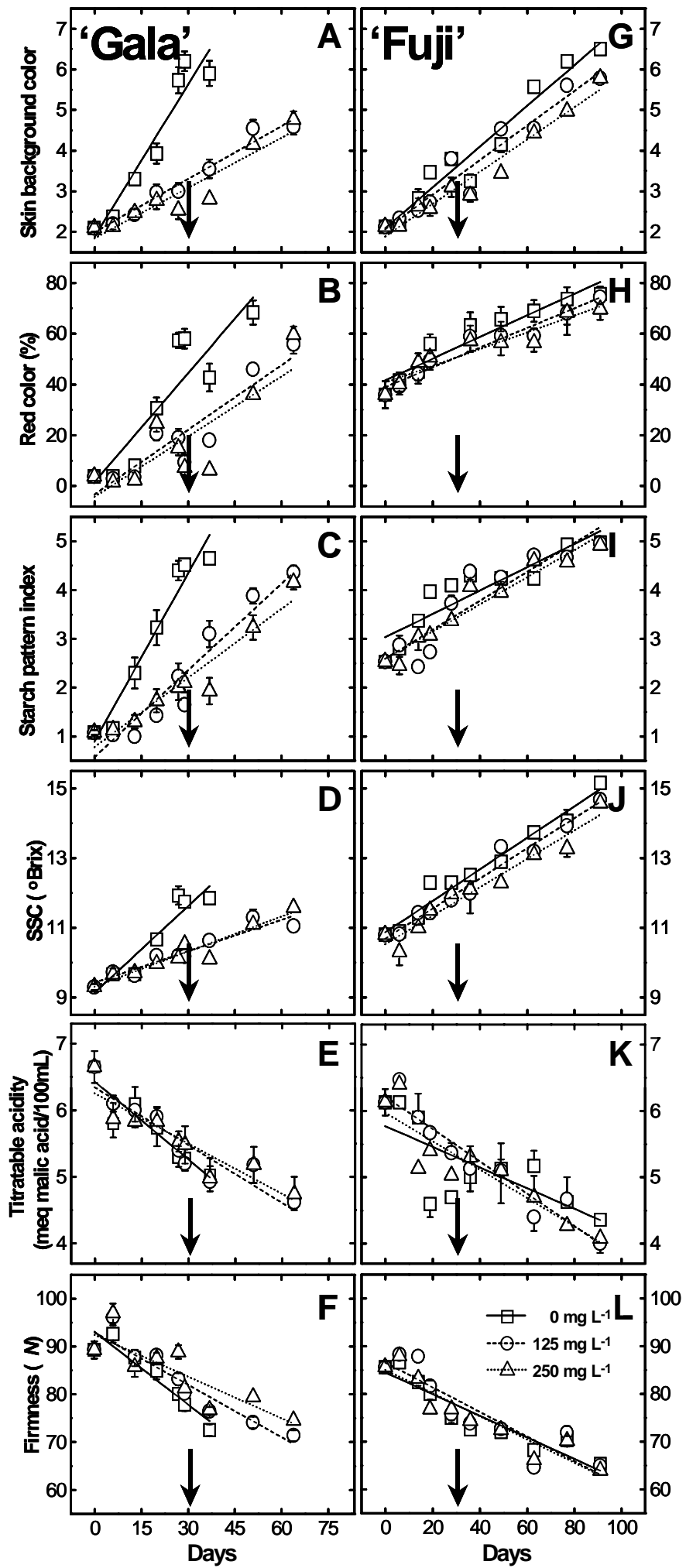

FIGURE 2 - Effects of AVG on skin background color (A, G), red color of the skin $(B, H)$, starch pattern index $(C, I)$, soluble solids content (SSC; D, J), titratable acidity (E, K), and flesh firmness (F, L) of 'Gala' (on the right) and 'Fuji' (on the left) apples. The bars represent the standard error of the means $(n=4)$. Arrows indicate the initial commercial harvest for the control treatment of each cultivar. The $x$ axis represents days after AVG spraying.

However, ethylene biosynthesis inhibition by AVG on 'Gala' apples had differential impacts on different maturity attributes. The visual aspect might fail to match the fruit sensory attributes. The fruit might have poor skin color (dark-green background and deficient red color development) while still being able to mobilize starch, soften, and lose acidity on the tree. This might result in misjudgment during scheduling of harvesting time to achieve the best storage potential of AVG treated fruit. The reduced red color of the skin from AVG treatments impacts negatively on fruit quality. Nevertheless, this negative effect of AVG can be reversed by the application of ethephon close to the harvest (Wang \& Dilley, 2001).

\section{CONCLUSIONS}

1. AVG substantially suppressed preharvest fruit drop and delayed fruit maturity on 'Gala' but not on 'Fuji';

2. On 'Gala', the AVG dose of $125 \mathrm{mg} \mathrm{L}^{-1}$ might be used commercially to delay fruit harvest and increase yield by reducing premature fruit abscission and increasing fruit size of late harvested fruit;

3. Fruit treated with AVG had poor skin color (dark-green background and deficient red color development) while still being able to mobilize starch, soften, and lose acidity on the tree.

\section{ACKNOWLEDGMENTS}

The authors are grateful to Yakult S.A. (Lages, SC) for their support in conducting the field works.

\section{REFERENCES}

AUTIO, W.R.; BRAMLAGE, W.J. Effects of AVG on maturation, ripening, and storage of apples. Journal of the American Society for Horticultural Science, Alexandria, v. 107, n. 6, p. 1074-1077, 1982.

BRAMLAGE, W.J.; GREENE, D.W.; AUTIO, W.R.; MCLAUGHLIN, J.M. Effects of aminoethoxyvinilglycine on internal ethylene concentrations and storage of apples. Journal of the American Society for Horticultural Science, Alexandria, v. 105, n. 6, p. 847-851, 1980.

CLAYTON, M.; BIASI, W.V.; SOUTHWICK, S.M.; MITCHAM, E.J. ReTain $^{\mathrm{TM}}$ affects maturity and ripening of 'Bartlett' pear. HortScience, Alexandria, v. 35, n. 7, p. 1294-1299, 2000.

DEKAZOS, E.D. Effect of aminoethoxyvinylglycine on bloom delay, fruit maturity, and quality of 'Loring' and 'Rio Oso Gem' peaches. HortScience, Alexandria, v. 16, n. 4, p. 520-522, 1981.

FAN, X.; MATTHESIS, J.P.; BUCHANAN, D. Continuous requirement of ethylene for apple fruit volatile synthesis. Journal of Agricultural and Food Chemistry, Columbus, v. 46, n. 5, p. 1959-1963, 1998.

FAUST, M. Physiology of temperate zone fruit trees. New York: John Wiley \& Sons, Inc., 1989. 338 p.

HARB, J.; STREIF, J.; BANGERTH, F. Response of controlled atmosphere (CA) stored 'Golden Delicious' apples to the treatments with alcohols and aldehydes as aroma precursors. Gartenbauwissenschaft, Stuttgart, v. 65, n. 4, p. 154-161, 2000.

JU, Z.; DUAN, Y.; JU, Z. Combinations of $\mathrm{GA}_{3}$ and AVG delay fruit maturation, increase fruit size and improve storage life of 'Feicheng' peaches. Journal of Horticultural Science \& Biotechnology, Kent, v. 74 , n. 5 , p. $579-583,1999$.

JU, Z.; BRAMLAGE, W.J. Cuticular phenolics and scald development in 'Delicious' apples. Journal of the American Society for Horticultural Science, Alexandria, v. 125, n. 4, p. 498-504, 2000.

LAYNE, D.R.; JIANG, Z.; RUSHING, J.W. The influence of reflective film and ReTain on red skin color and maturity of 'Gala' apples in South Carolina. HortScience, Alexandria, v. 35, n. 3, p. 495, 2000.

MANRIQUEZ, D.; DEFILIPPI, B.; RETAMALES, J. AVG, an ethylene biosynthesis inhibitor: its effects on ripening and softening in kiwifruit. Acta Horticulturae, Leuven, n. 498, p. 263-275, 1999.

MASIA, A.; VENTURA, M.; GEMMA, H.; SANSAVINI, S. Effect of some plant growth regulator treatments on apple fruit ripening. Plant Growth Regulation, Dordrecht, v. 25, n. 2, p. 127-134, 1998.

MIR, N.A.; PEREZ, R.; SCHWALLIER, P.; BEAUDRY, R. Relationship between ethylene response manipulation and volatile production in 
Jonagold variety apples. Journal of Agricultural and Food Chemistry, Washington, v. 47, n. 7, p. 2653-2659, 1999.

ROMANI, R.; LABAVITCH, J.; YAMASHITA, T.; HESS, B., RAE, H. Preharvest AVG treatment of 'Bartlett' pear fruits: effects on ripening, color change, and volatiles. Journal of the American Society for Horticultural Science, Alexandria, v. 108, n. 6, p. 1046-1049, 1983.

SAQUET, A.A.; STREIF, J. Investigations on the respiration and the ethylene production of some new apple cultivars. Erwerbsobstbau, Berlin, v. 42, n. 4, p. 109-112, 2000.

SAS. Cary: SAS institute, 1990.789 p.

SHELLIE, K.C. Muskmelon (Cucumis melo L.) fruit ripening and postharvest quality after a preharvest spray of aminoethoxyvinylglycine. Postharvest Biology and Technology, Amsterdam, v. 17, n. 1, p. 55-62, 1999.

STARRETT, D.A.; LATIES, G.G. Involvement of wound and climacteric ethylene in ripening avocado discs. Plant Physiology, Rockville, v. 97, n. 2, p. 720-729, 1991.

WANG, Z.; DILLEY, D.R. Aminoethoxyvinylglycine, combined with ethephon, can enhance red color development without over-ripening apples. HortScience, Alexandria, v. 36, n. 2, p. 328-331, 2001.

WARD, D.L.; BEERS, E.P.; BYERS, R.E., MARINI, R.P. Cutting apple fruits induces cellulase activity in the abscission zone. HortScience, Alexandria, v. 34, n. 4, p. 601-603, 1999.

WILLIAMS, M.W. Retention of fruit firmness and increase in vegetative growth and fruit set of apples with aminoethoxyvinylglycine. HortScience, Alexandria, v. 15, n. 1, p. 76-77, 1980.

YANG, S.F.; HOFFMAN, N.E. Ethylene biosynthesis and its regulation in higher plants. Annual Review of Plant Physiology, Palo Alto, v. 35, p. 155-189, 1984. 